\title{
Characteristics of a Wavelength-swept Laser with a Polygon-based Wavelength Scanning Filter
}

\author{
Myeong Ock Ko ${ }^{1}$, Namje Kim², Sang-Pil Han², Kyung Hyun Park ${ }^{2}$, Bong Wan Lee ${ }^{3}$, \\ and Min Yong Jeon ${ }^{1 \dagger}$ \\ ${ }^{1}$ Department of Physics, Chungnam National University, Daejeon 305-764, Korea \\ ${ }^{2}$ THz Photonics Creative Research Center, ETRI, Daejeon 305-700, Korea \\ ${ }^{3}$ Fiberpro Inc., Daejeon 305-343, Korea
}

(Received March 5, 2014; Revised manuscript March 20, 2014; Accepted March 21, 2014)

\begin{abstract}
We report the characterization of a wavelength-swept laser (WSL) using a polygon-based wavelength scanning filter and two semiconductor optical amplifiers (SOAs). The output intensity and scanning bandwidth of the WSL depend on the position of the two SOAs in the laser cavity and the coupling ratio of the output fiber coupler. The outputs of the WSL are characterized for coupling ratios of $10 \%, 30 \%, 50 \%, 70 \%$, and $90 \%$ for the output fiber coupler. In the setup in which the output fiber coupler is located between the two SOAs, high output power and wide scanning bandwidth can be achieved with an optimized configuration. Using the optimized configuration of the WSL, the intensity increases with the coupling ratio. These results can be used to construct an optimized WSL using the polygon-based wavelength scanning filter.
\end{abstract}

Keywords: Wavelength-swept laser, Semiconductor optical amplifer, Polygon-based wavelength scanning filter OCIS codes: (140.3280) Laser amplifiers; (140.3460) Lasers; (140.3510) Lasers, Fiber

\section{다면체 거울 스캐닝 파장 필터를 이용한 파장 흩음 레이저의 출력 특성 고명옥 $^{1} \cdot$ 김남제 $^{2} \cdot$ 한상필 $^{2} \cdot$ 박경현 $^{2} \cdot$ 이봉완 $^{3} \cdot$ 전민용 $^{\dagger \dagger}$ \\ 1충남대학교 물리학과 \\ (9) 305-764 대전광역시 유성구 대학로 99번지 \\ ${ }^{2}$ 한국전자통신연구원 $\mathrm{THz}$ 포토닉스 창의연구센터 \\ (ㄱ) 305-700 대전시 유성구 가정로 218번지 \\ ${ }^{3}$ (주)파이버프로 중앙연구소 \\ (ㄱ) 305-343 대전광역시 유성구 가정북로 26-55번지}

(2014년 3월 5일 받음, 2014년 3월 20일 수정본 받음, 2014년 3월 21일 게재 확정)

본 논문에서는 두 개의 반도체 광 증폭기 $(\mathrm{SOA})$ 와 다면체 거울 스캐닝 파장 필터를 이용한 파장 훓음 레이저의 특성을 보고한 다. 파장 훓음 레이저의 출력 세기 및 파장 훓음 범위는 레이저 공진기에서 두 개의 SOA와 출력 광 커플러의 위치 및 커플링 비율에 의존한다. 본 연구에서는 크게 두 가지 광 배열에 대해 출력 광 커플러의 커플링 비율을 $10 \%, 30 \%, 50 \%, 70 \%, 90 \%$ 로 바꾸어 가면서 파장 훓음 속도에 따른 파장 훓음 범위와 광 출력을 비교 분석하였다. 두 SOA 사이에 광 커플러를 둔 최적화된 배열에서 비교적 높은 출력과 넓은 파장 훓음 범위를 얻을 수 있었다. 이 배열에서는 출력 광 커플러의 커플링 비율이 증가함에 따라 광 출력도 증가하는 것을 볼 수 있었다. 이러한 결과는 다면체 거울 스캐닝 필터를 이용하여 파장 훝음 레이저를 제작할 때 최적의 레이저 공진기 구성에 많은 도움이 될 것으로 기대한다.

Keywords: 파장 훝음 레이저, 반도체 광 증폭기, 다면체 파장 필터

OCIS codes: (140.3280) Laser amplifiers; (140.3460) Lasers; (140.3510) Lasers, Fiber

\footnotetext{
${ }^{\dagger}$ E-mail: myjeon@cnu.ac.kr

Color versions of one or more of the figures in this paper are available online.
} 


\section{I. 서 론}

파장 훓음 레이저 (wavelength swept laser)는 최근 바이오 포토닉스의 광 간섭성 단층 영상 촬영 시스템의 광원으로 상 당한 발전을 이루었으며, 최근에는 다이나믹 광섬유 센서와 테라헤르츠 파 발생을 위한 주파수 가변 비팅 광원으로도 연 구가 되고 있다. ${ }^{[1-11]}$ 파장 훓음 레이저는 파장 훓음 속도의 향상과 넓은 파장 훓음 영역을 구현하기 위해 여러 가지 방 법으로 개발되었다. ${ }^{[1-8]}$ 회절 격자와 거울을 이용하는 방법, 광섬유 일체형 Fabry-Perot 가변 필터를 이용하는 방법 및 다 면체 거울 스캐닝 파장 필터를 이용하는 방법 등이 있다. 회 절 격자와 거울을 이용하는 파장 훓음 레이저는 정밀한 광 정렬이 필요하며, 또한 거울의 회전이 벌크하기 때문에 높은 속도의 파장 훓음 레이저를 구현하기가 어렵다. 광섬유 일체 형 Fabry-Perot 가변 필터를 이용한 파장 훓음 레이저는 모든 소자가 광섬유로 되어 있어서 별도의 광 정렬이 필요 없고 구성이 용이하며 쉽게 구현할 수 있는 장점이 있지만, 필터 의 열적 불안정성으로 중심 파장이 안정적이지 못한 단점이 있다. 또한 필터에 걸어주는 신호가 sine파이기 때문에 파장 이동이 선형적이지 않아서 파수 영역에서 선형화를 위한 별 도의 신호처리 과정이 필요하다. ${ }^{[1,12]}$ 반면에 다면체 거울 스캐닝 파장 필터를 이용한 파장 훓음 레이저는 자유공간에 서의 정밀한 광 정렬이 필요하여 광 손실이 크고 구현하기가 용이하지 않는 단점이 있지만, 고속으로 파장을 가변 할 수 있고, 열적인 불안정성이 없어서 안정적인 파장 훓음 특성을 얻을 수 있는 장점이 있다. 바이오 포토닉스에서 사용하는 파장 훓음 레이저 광원은 실시간 이미징과 분해능 향상을 위 해 빠른 훓음 속도와 넓은 밴드 폭을 갖는 광대역 광원이 요 구된다. ${ }^{[3,5]}$ 반면에 테라헤르츠 파 발생을 위한 주파수 가변 비팅 광원에서는 넓은 밴드 폭 보다는 높은 광 출력과 좁은 순간 선폭, 안정적인 파장으로 가변되는 특성을 요구한다. 따라서 파장 필터로써 Fabry-Perot 가변 필터를 이용하는 것 보다 다면체 거울 스캐닝 파장 필터를 사용하여 파장 훓음 레이저를 구현하는 것이 테라헤르츠 파 발생을 위한 주파수 가변 비팅 광원을 얻기에 더 적합하다.

파장 훓음 레이저의 출력 특성에서 중요한 요소들은 파장 훓음 속도와 훓음 밴드 폭 및 출력 파워이다. 파장 훓음 레 이저에서 파장 훓음 속도를 높이기 위한 다양한 방법이 개발 되었는데, Fabry-Perot 가변 필터를 이용하여 파장 훓음 속도 를 높이기 위해 개발된 방법이 분광영역 모드록킹 파장 훓음 레이저이다. ${ }^{[3]}$ 또한 다면체 거울을 이용한 파장 훓음 레이저 에서는 다면체에서 빛이 여러번 반사를 일으키도록 하고, 또 한 출력된 신호를 광섬유 지연선로를 이용하여 시간영역에 서 다중화하는 방법으로 $400 \mathrm{kHz}$ 이상의 높은 훓음 속도로 구현한 결과가 보고되었다. ${ }^{[10]}$ 이때 파장 훓음 레이저의 이득 매질로는 주로 반도체 광 증폭기가 사용되는데, 이는 이득 영역이 넓어서 넓은 파장 훏음 영역을 얻기에 적합하기 때문 이다. 또한 높은 출력을 얻기 위해서는 하나의 반도체 광 증 폭기에서 얻을 수 있는 이득에 한계가 있기 때문에 두 개를
사용하여 구현할 수 있다. 보통 파장 훓음 레이저 출력 단 뒤에 증폭기용으로 추가의 광 증폭기를 사용하기도 하지만, 공진기 안에 두 개의 반도체 광 증폭기를 삽입하면 높은 출 력 뿐만 아니라 넓은 밴드폭도 얻을 수도 있다.

본 연구에서는 다면체 거울 스캐닝 파장 필터를 이용하여 반도체 광 증폭기 2 개와 다양한 출력 커플러 비율을 갖는 소 자의 배열에 따른 파장 훓음 레이저의 출력 특성을 분석한 결과를 보고한다. 파장 훓음 레이저의 용도에 따라 높은 출 력보다는 넓은 밴드 폭을 요구 할 수도 있고, 또 다른 용도 에 따라서는 넓은 밴드 폭 보다는 높은 출력을 우선으로 할 수도 있다. 본 연구에서는 테라헤르츠 파 발생을 위한 주파 수 가변 비팅 광원을 구현하기 위하여 높은 출력을 얻기 위 한 최적의 광소자 배열을 찾아내고 그에 따른 파장 훓음 레 이저의 출력 특성을 분석한 결과를 보고한다.

\section{II. 실험 및 결과}

\section{1. 다면체 거울 스캐닝 파장 필터}

그림 1 은 본 연구에서 제작한 다면체 거울 스캐닝 파장 필 터의 모식도이다. 이 필터는 600 grooves $/ \mathrm{mm}$ 의 반사형 회절격자 (diffraction grating), 초점거리 $F_{1}, F_{2}$ 가 각각 $100 \mathrm{~mm}, 45$ $\mathrm{mm}$ 인 렌즈 (Achromatic doublets) 1, 2 로 구성된 무한초점 망 원경 (afocal telescope) 및 36면의 다면체 스캐닝 거울 (polygon scanning mirror)로 구성된다. 콜리메이터에서 나온 평행 빔은 반사형 회절격자에 의해 분광되고, 첫 번째 회절 된 빔의 중심파장이 망원경의 광축과 일치하도록 정렬한다. 회절격자 방정식은 $\lambda_{0}=p\left(\sin \alpha+\sin \beta_{0}\right)$ 이며, 여기서 $\lambda_{0}$ 는 분광된 빛의 중심파장, $p$ 는 회절격자 간격, $\alpha, \beta_{0}$ 는 각각 회 절격자 법선에 대한 입사각과 회절각이다. 중심파장 1330 $\mathrm{nm}$ 에서의 회절 효율 (diffraction efficiency)이 최대가 되도 록 광 정렬하였다. 이때 회절격자에 의해 분광되어 $\Delta \beta$ 의 각 으로 퍼져 진행하는 빛이 망원경을 지나 다각형 거울 스캐너 회전축 중심을 향하여 수렴각 $\left(\Delta \beta^{\prime}\right)$ 으로 입사하도록 회절격 자와 다각형 거울 스캐너를 각 렌즈의 초점거리에 고정한다. 다면체 거울에 입사하는 빛의 스펙트럼 중 한 번에 한 단파 장 성분만 입사경로를 되돌아가기 위해서는 다면체 면 사이 각 $(\Delta \theta)$ 보다 수렴각이 작아야 하고 (즉, $\Delta \theta>\Delta \beta^{\prime}$ ), 이때 거 울 면에 수직으로 입사한 빛만 다시 경로로 되돌아가 콜리메 이터로 들어가게 된다.

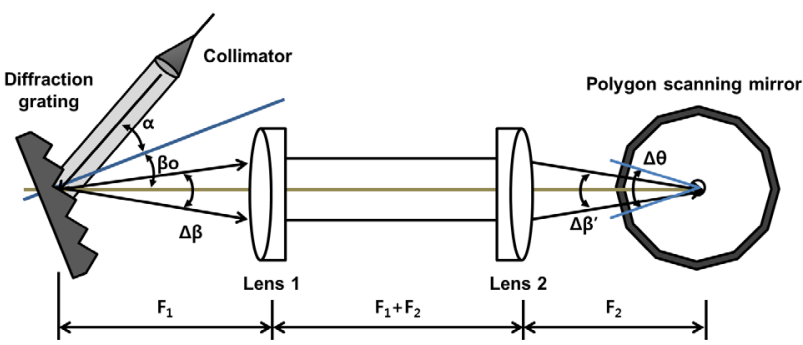

FIG. 1. Schematic of polygon-based wavelength scanning filter. 


\section{2. 다면체 거울 스캐닝 파장 필터를 이용한 파장 흩 음 레이저}

36 면을 갖는 다면체 거울 스캐닝 파장 필터를 이용한 파장 훝음 레이저 배열에서 두 $\mathrm{SOA}$ 와 출력 광 커플러의 위치, 그 리고 각 배열에서 광 출력비율에 따른 레이저 출력 특성을 비교 분석하였다. 사용한 $\mathrm{SOA} 1$ (BOA, Covega)은 중심파장 이 $1330 \mathrm{~nm}$ 이고, $3 \mathrm{~dB}$ 밴드 폭이 약 $75 \mathrm{~nm}$ (@ $600 \mathrm{~mA}, 2$ $5^{\circ} \mathrm{C}$ )이며, SOA 2 (BOA, Covega)는 중심파장이 $1308 \mathrm{~nm}$ 이 고, $3 \mathrm{~dB}$ 밴드 폭이 약 $84 \mathrm{~nm}\left(@ 700 \mathrm{~mA}, 25^{\circ} \mathrm{C}\right)$ 이다. 이에 대한 amplified spontaneous emission (ASE) 스펙트럼이 그림 2에 나타나 있다. 레이저 공진기 안에 광 서큘레이터가 있어 서 빛은 반시계 방향으로만 진행한다. 실험에 사용한 $\mathrm{SOA}$ 는 편광 의존성을 갖고 있기 때문에 발진하는 모든 파장에서 균 일하게 발진하도록 그림 3 과 같이 각 $\mathrm{SOA}$ 입력단에 편광 조

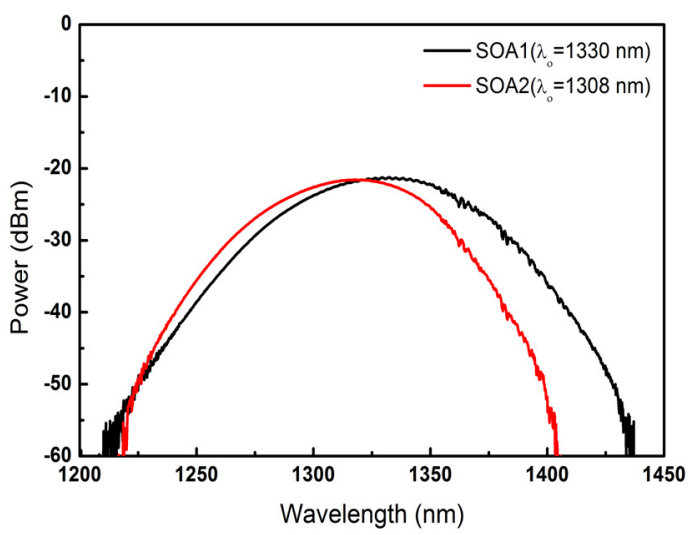

FIG. 2. Optical spectra of the amplified spontaneous emission (ASE) of two SOAs.

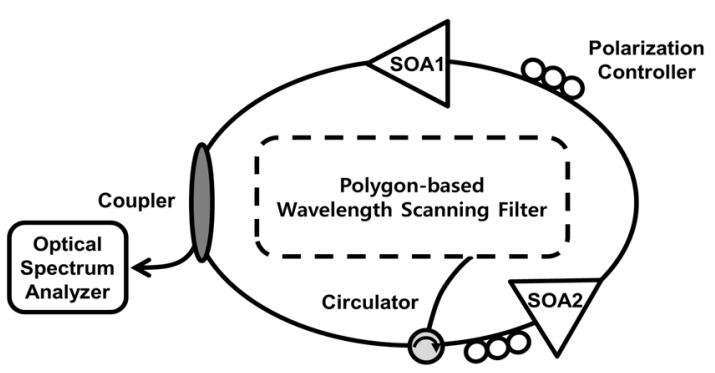

(a)

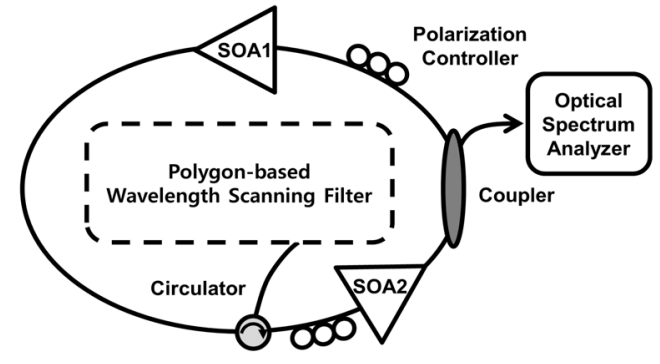

(b)

FIG. 3. Experimental set-ups according to the position of optical fiber coupler.
절기 (polarization controller)를 삽입하였다.

먼저 2개의 SOA와 출력 광 커플러의 배열을 그림 3(a), (b)와 같이 위치시켰을 때의 파장 훝음 레이저 출력을 측정 하였다. 그림에서 점선으로 나타낸 것은 다면체 거울 스캐닝 파장 필터를 나타낸다. 레이저 출력 특성을 비교하기 위해 사용한 출력 광 커플러는 총 3 가지로 $10: 90,30: 70,50: 50$ 이 다. 각각의 조합을 바꾸어 총 5 개의 배열에 대한 출력 특성 을 분석하였다. 첫 번째 배열은 그림 3(a)와 같으며, 다면체 거울 스캐닝 파장 필터 다음에 두 개의 $\mathrm{SOA}$ 를 배열한 뒤 출 력 광 커플러를 연결하여 파장 훝음 레이저의 출력을 측정하 였다. 이 경우 출력 광 커플러에 의해 일부 빛은 출력되고 나머지 빛만 필터 안으로 들어가게 되므로 광 커플러가 감쇠 기 역할을 하게 된다. 필터에 의해 가변 된 빛의 세기는 입 력 신호에 대해 약 $25 \mathrm{~dB}$ 정도 감소하며, 편광 조절기 및 다 른 연결 손실 등에 의해 약 $30 \mathrm{~dB}$ 손실이 일어난다. 신호 세 기가 약한 파장 대역은 $\mathrm{SOA}$ 를 통과한 뒤에 증폭되지 못하 여 그 파장 대역은 $\mathrm{SOA}$ 의 $\mathrm{ASE}$ 신호만 출력된다. 즉 출력 광 커플러의 출력 비율이 높아지면 입력신호의 광 손실이 커 지기 때문에 필터를 거친 반사신호 중, $\mathrm{SOA}$ 까지 도달하기 전에 소실되는 파장 영역이 증가하여 결국 파장 홇음 범위가 좁아지게 될 것으로 예측할 수 있다. 두 번째 배열은 그림 3(b)와 같으며, 출력 광 커플러의 위치를 두 SOA 사이에 두 어 파장 훝음 레이저의 출력을 측정하였다. 이 배열에서는 출력 광 커플러에 의해서 $\mathrm{SOA} 2$ 의 $\mathrm{ASE}$ 신호 중 일부만 $\mathrm{SOA} 1$ 에 입사되어 증폭되고, 이 빛이 다면체 스캐닝 파장 필터로 입사한다. 이때 다면체 스캐닝 파장 필터의 전체 광 손실이 $30 \mathrm{~dB}$ 가 되더라도 그림 $3(\mathrm{a})$ 의 경우보다 더 넓은 파 장영역이 발진 가능한 이득을 가지고 있기 때문에 상대적으 로 높은 출력과 넓은 밴드 폭을 가질 수 있다. 이때, 필터로 부터 스캐닝 된 빛은 $\mathrm{SOA} 2$ 에 의해 다시 증폭된 후 출력 광 커플러를 통과하므로 결과적으로 레이저특성이 그림 3(a)의 배열보다 높은 출력과 넓은 밴드 폭을 보일 것으로 예상할 수 있다.

그림 4는 파장 훓음 레이저의 배열을 그림 3에서 (a)로 했 을 때와 (b)로 했을 때 출력 광 커플러의 커플링 비율에 따른 파장 훓음 폭을 나타낸 것이다. 파장 훝음 레이저의 훝음 속 도를 $10 \mathrm{kHz}$ 로 구동하고, 출력 광 커플러의 커플링 비율을 $10 \%, 30 \%, 50 \%, 70 \%, 90 \%$ 로 바꾸어 가면서 파장 훓음 폭 을 측정하였다. 그림에서 보듯이 그림 $3(\mathrm{a})$ 의 배열로 했을 때, 출력 광 커플러의 비율이 $10 \%$ 와 $30 \%$ 일 때는 각각 82.8 $\mathrm{nm}$ 와 $80.8 \mathrm{~nm}$ 이고, $50 \%, 70 \%$, 및 $90 \%$ 일 때는 각각 71.9 $\mathrm{nm}, 73 \mathrm{~nm}$, 및 $62.2 \mathrm{~nm}$ 로 얻어졌다. 그림 3 (a)의 배열에서 는 출력 광 커플러의 비율이 증가함에 따라 파장 훓음 폭이 큰 폭으로 감소하는 것을 볼 수 있다. 이는 앞에서 분석한 것과 일치하는 것으로, 출력 광 커플러의 출력 비율이 높으 면 레이저 공진기 내로 되먹임 되는 빛의 세기가 상대적으로 낮아져서 필터를 통과한 광신호가 큰 손실을 겪게 되어 전체 적으로 파장 훓음 범위가 좁아지게 된 것이다. 그림 3 (b)배 열에 대해서는 출력 광 커플러의 커플링 비율에 상관없이 모 


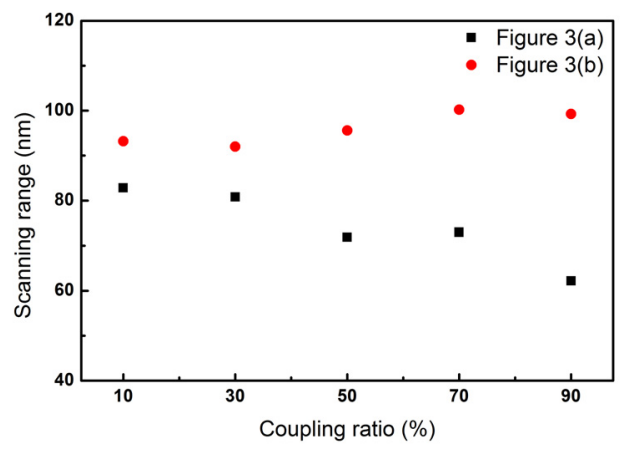

FIG. 4. Wavelength tuning ranges of the laser according to the coupling ratios of the output couplers for two configurations (a) $25^{\circ} \mathrm{C}$ ).

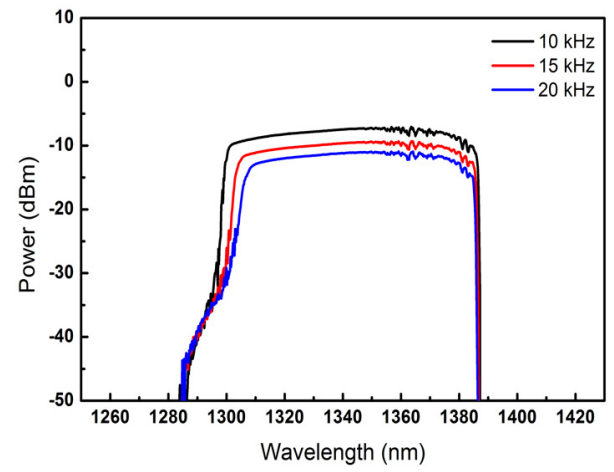

(a) $10 \%$ output coupler

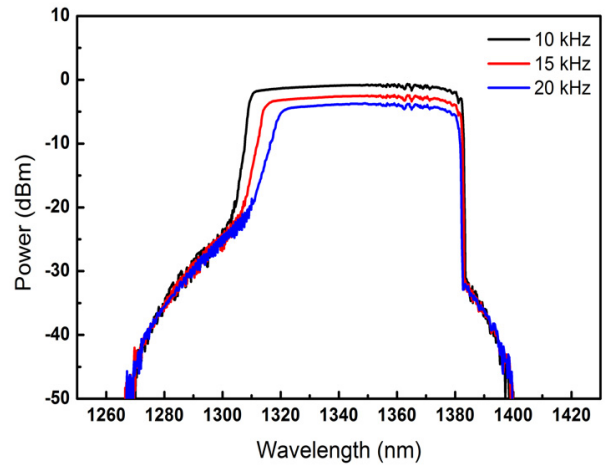

(c) $50 \%$ output coupler

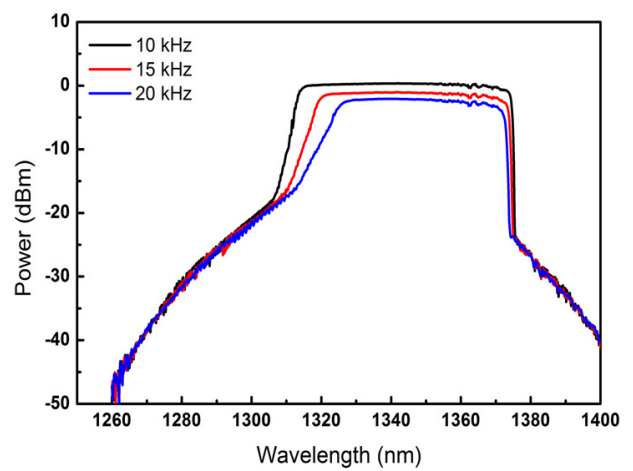

(e) $90 \%$ output coupler
두 파장 훓음 범위가 $90 \mathrm{~nm}$ 이상으로 얻어졌으며, 커플링 비율이 $70 \%$ 일 때 $100.2 \mathrm{~nm}$ 로 최대 파장 훓음 범위를 얻을 수 있었다. 그림 4의 결과로부터 효율적인 출력 광 커플러의 위치는 두 배열 중 그림 3 (b)의 배열이며, 이 때 출력 광 커 플러의 커플링 비율과 무관하게 $90 \mathrm{~nm}$ 이상의 넓은 파장 훓 음 범위를 얻어낼 수 있었다.

그림 5(a) (e)는 파장 훓음 레이저의 배열을 그림 3(a)의 배 열로 하였을 때 $10 \%$ 90\%의 출력 광 커플러의 비율에서 훓 음 속도에 따른 파장 훓음 범위를 보여주는 광 스펙트럼이 다. 그림에서 보듯이 출력 광 커플러의 커플링 비율이 증가 할수록 측정한 파장 훓음 범위가 큰 폭으로 감소하는 것을 볼 수 있다. 또한, 모든 커플링 비율에서 훓음 속도를 10

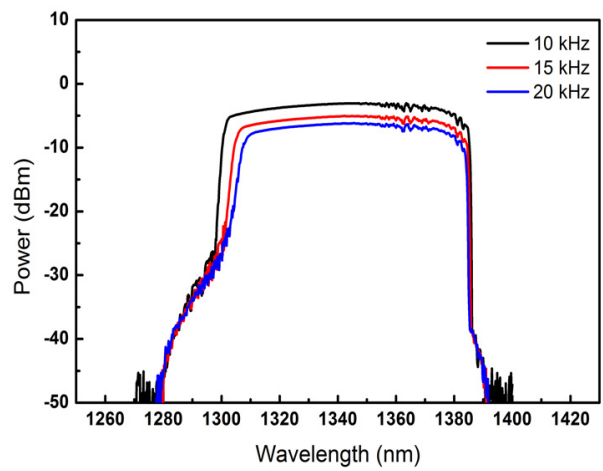

(b) $30 \%$ output coupler

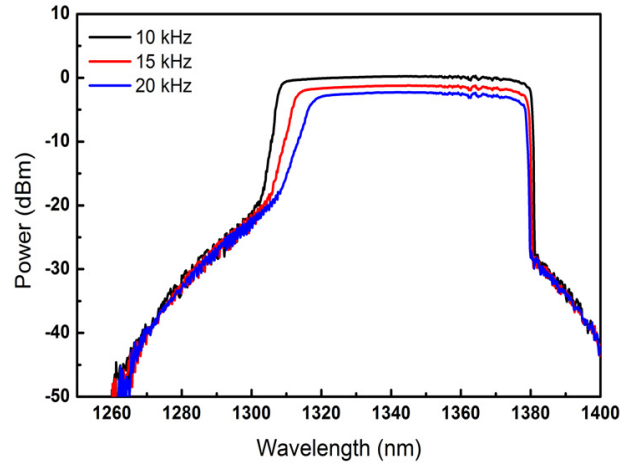

(d) $70 \%$ output coupler
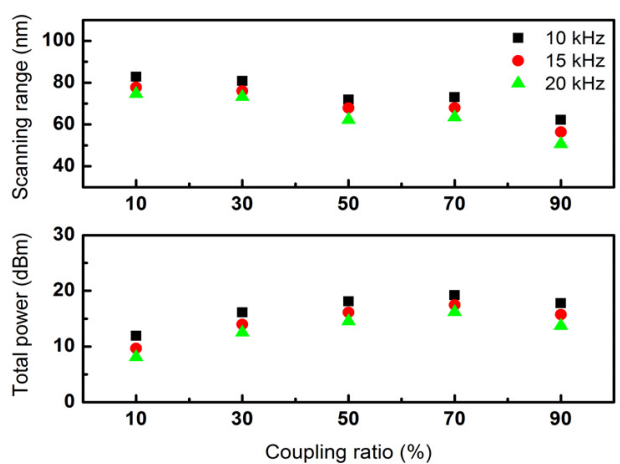

(f)

FIG. 5. (a) (e) The scanned spectra and (f) the wavelength tuning range (up) and total power (down) of the laser at several coupling ratios and wavelength scanning speeds at configuration Fig. 3(a) (@ 25 ${ }^{\circ} \mathrm{C}$ ). 
$\mathrm{kHz}$ 에서 $20 \mathrm{kHz}$ 까지 증가시키면서 파장 훓음 범위를 측정 한 결과 그 범위가 감소하는 것을 볼 수 있다. 이는 훓음 속 도가 빠를수록 SOA에서 비선형특성인 frequency downshift 현상이 두드러지기 때문에 파장 훓음 범위가 감소하는 것으 로 예측된다. ${ }^{[13]}$ 그림 5(f)는 그림 3(a)의 배열에 대해 10 $\mathrm{kHz}, 15 \mathrm{kHz}, 20 \mathrm{kHz}$ 에서 출력 광 커플러의 커플링 비율에 따른 광 출력과 파장 훓음 범위를 보여준다. 이때 스펙트럼 은 OSA(Optical spectrum analyzer)의 peak hold mode로 측 정했고, 전체 파워는 파장에 따른 평균 출력세기를 전 파장 에 대해 적분한 값이다. 출력 광 커플러의 커플링 비율과 상 관없이 파장 훓음 속도가 커지면 광 출력은 반대로 줄어드는 것을 볼 수 있다. 광 출력은 출력 광 커플러의 비율이 $70 \%$ 일 때 가장 높은 출력을 얻었으며 $10 \%$ 일 때 가장 낮은 출력을
얻었다. 반면 파장 훓음 범위는 출력 광 커플러의 커플링 비 율이 $10 \%$ 일 때 가장 넓었고, 커플링 비율이 증가할수록 점 차 낮아져서 $90 \%$ 일 때는 큰 폭으로 감소함을 볼 수 있다. 그리고 그림 5(f)에서 보듯이 커플링 비율의 증가와 더불어 파장 훓음 속도가 증가하면 파장 훓음 범위는 더욱 좁아지는 것을 볼 수 있다.

그림 6(a) (e)는 파장 훓음 레이저의 배열을 그림 3(b)의 배열로 하였을 때 $10 \%$ $90 \%$ 의 출력 광 커플러의 커플링 비 율에서 훓음 속도에 따른 파장 훓음 범위를 보여주는 광 스 펙트럼이다. 이 배열에서는 출력 광 커플러의 커플링 비율이 증가하더라도 측정한 파장 훓음 범위는 큰 변화가 없으며, 오히려 $70 \%$ 의 커플링 비율에서 파장 훓음 범위가 $100 \mathrm{~nm}$ 이 상으로 얻어진 것을 볼 수 있다. 전체적으로 이 배열에서는

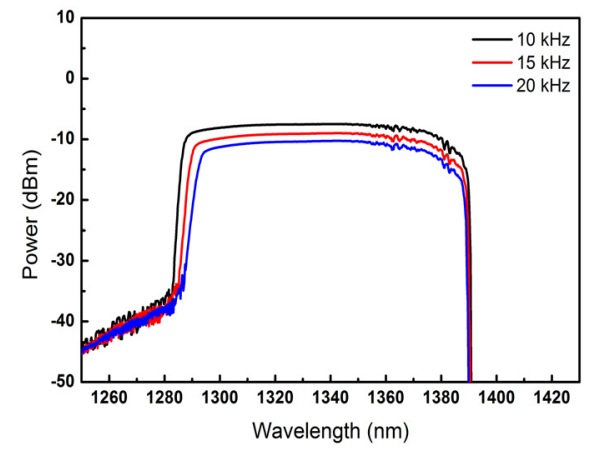

(a) $10 \%$ output coupler

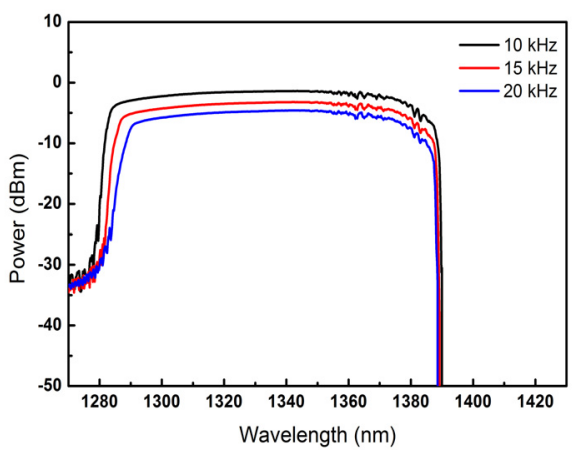

(c) $50 \%$ output coupler

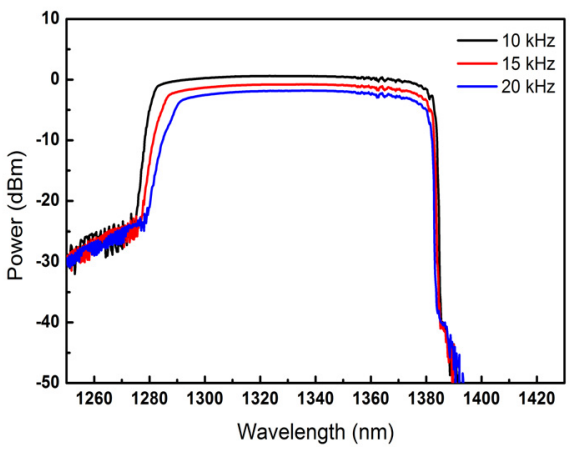

(e) $90 \%$ output coupler

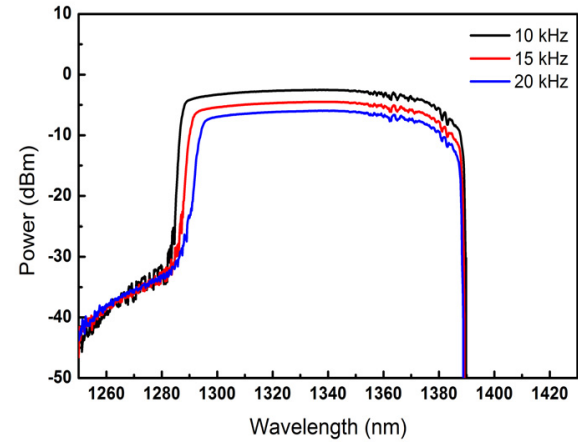

(b) $30 \%$ output coupler

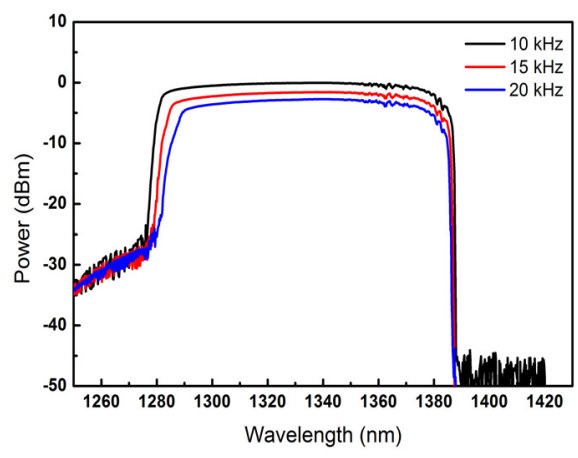

(d) $70 \%$ output coupler
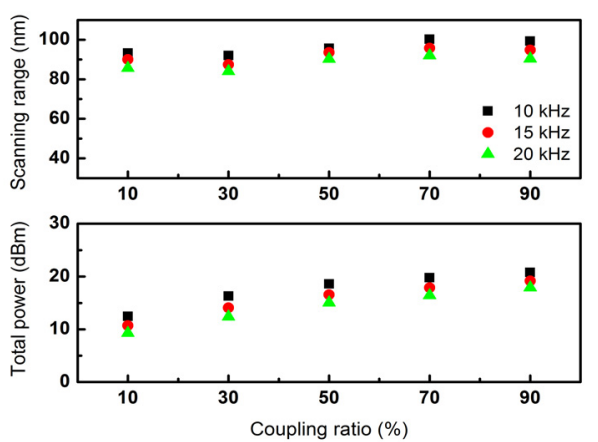

(f)

FIG. 6. (a) (e) The scanned spectra and (f) the wavelength tuning range (up) and total power (down) of the laser at several coupling ratios and wavelength scanning speeds at configuration Fig. 3(b) (@ 25 $\left.{ }^{\circ} \mathrm{C}\right)$. 
커플링 비율에 따른 파장 훓음 범위의 변화가 $10 \%$ 이내에서 유지되는 것을 볼 수 있다. 그림 6(f)는 그림 3(b)의 배열에 대해 $10 \mathrm{kHz}, 15 \mathrm{kHz}, 20 \mathrm{kHz}$ 에서 출력 광 커플러의 커플링 비율에 따른 광 출력과 파장 훓음 범위를 보여준다. 그림 $5(\mathrm{f})$ 와 마찬가지로 출력 광 커플러의 커플링 비율과 상관없 이 $10 \mathrm{kHz}$ 일 때가 $20 \mathrm{kHz}$ 일 때보다 넓은 파장 훓음 범위를 얻어낼 수 있으며, 또한 광 출력이 더 큰 것을 볼 수 있다. 그리고 출력 광 커플러의 비율이 증가함에 따라 광 출력도 증가하는 것을 볼 수 있다. 커플링 비율이 $90 \%$ 일 때 가장 높 은 출력을 얻었으며 이 때 광 출력은 $20 \mathrm{dBm}$ 이상을 얻을 수 있었다.

\section{III. 결 론}

본 연구에서는 다면체 거울 스캐닝 파장 필터를 이용한 파 장 훓음 레이저의 배열 및 출력커플러 비율에 따른 출력 특 성을 분석하였다. 반도체 광 증폭기 2개와 다양한 출력 커플 러 비율을 갖는 소자의 배열을 달리했을 때, 그리고 파장 훓 음 속도에 따라 출력 광 커플러의 비율을 $10 \%, 30 \%, 50 \%$, $70 \%, 90 \%$ 로 바꾸었을 때의 파장 훓음 범위와 광 출력을 비 교 분석하였다. 두 번째 SOA 빔의 일부가 첫 번째 SOA 에 의해 증폭된 후 다면체 스캐닝 파장 필터를 거쳐 다시 두 번 째 $\mathrm{SOA}$ 에 의해 증폭된 신호를 출력 광 커플러에서 측정했 을 때 높은 출력과 넓은 파장 훓음 범위를 얻을 수 있음을 보았다. 이 배열에서는 출력 광 커플러의 커플링 비율이 증 가하더라도 파장 훓음 범위는 크게 변하지 않았으며, 전체적 인 파장 훓음 범위의 변화는 $10 \%$ 이내에서 유지되는 것을 볼 수 있었다. 또한 이 배열에서 출력 광 커플러의 비율이 증가함에 따라 광 출력도 증가하는 것을 볼 수 있었으며, 10 $\mathrm{kHz}$ 파장 훓음 속도에서 커플링 비율을 $90 \%$ 로 사용하면 20 $\mathrm{dBm}$ 이상의 출력과 $100 \mathrm{~nm}$ 의 넓은 파장 훓음 범위를 얻을 수 있었다. 따라서 높은 출력을 요구하는 테라헤르츠 비팅 광원을 제작하는데 있어 본 연구의 결과를 활용할 수 있을 것으로 기대한다.

\section{감사의 글}

본 연구는 교육부와 한국연구재단의 지역혁신인력양성사 업(No. 2013H1B8A2032213) 및 정부(교육과학기술부)의 재 원으로 한국연구재단의 기초연구사업(2010-0022645)으로 수 행된 연구결과이다.

\section{References}

1. S. H. Yun, G. J. Tearney, J. F. de Boer, N. Iftimia, and B. E. Bouma, "High-speed optical frequency-domain imaging," Opt. Express 11, 2953-2963 (2003).

2. S. H. Yun, C. Boudoux, G. J. Tearney, and B. E. Bouma, "High-speed wavelength-swept semiconductor laser with a polygon-scanner-based wavelength swept filter," Opt. Lett. 28, 1981-1983 (2003).

3. R. Huber, M. Wojtkowski, and J. G. Fujimoto, "Fourier domain mode locking (FDML): A new laser operating regime and applications for optical coherence tomography," Opt. Express 14, 3225-3237 (2006).

4. S.-W. Lee, C.-S. Kim, and B.-M. Kim, "External line-cavity wavelength-swept source at $850 \mathrm{~nm}$ for optical coherence tomography," IEEE Photon. Technol. Lett. 19, 176-178 (2007).

5. M. Y. Jeon, J. Zhang, Q. Wang, and Z. Chen, "High-speed and wide bandwidth Fourier domain mode-locked wavelength swept laser with multiple SOAs," Opt. Express 16, 2547-2554 (2008).

6. E. J. Jung, C.-S. Kim, M. Y. Jeong, M. K. Kim, M. Y. Jeon, W. Jung, and Z. Chen, "Characterization of FBG sensor interrogation based on a FDML wavelength swept laser," Opt. Express 16, 16552-16560 (2008).

7. B. C. Lee, E.-J. Jung, C.-S. Kim, and M. Y. Jeon, "Dynamic and static strain fiber Bragg grating sensor interrogation with a $1.3 \mathrm{~mm}$ Fourier domain mode-locked wavelength-swept laser," Meas. Sci. Technol. 21, 094008 (2010).

8. B. C. Lee and M. Y. Jeon, "Remote fiber sensor based on cascaded Fourier domain mode-locked laser," Opt. Commun. 284, 4607-4610 (2011).

9. M. Y. Jeon, N. Kim, S.-P. Han, H. Ko, H.-C. Ryu, D.-S. Yee, and K. H. Park, "Rapidly frequency-swept optical beat source for continuous wave terahertz generation," Opt. Express 19, 18364-18371 (2011).

10. W.-Y. Oh, B. J. Vakoc, M. Shishkov, G. J. Tearney, and B. E. Bouma, " $>400 \mathrm{kHz}$ repetition rate wavelength-swept laser and application to high-speed optical frequency domain imaging," Opt. Lett. 35, 2919-2921 (2010).

11. B.-C. Lee, T.-J. Eom, and M. Y. Jeon, "K-domain linearization using fiber Bragg grating array based on fourier domain optical coherence tomography," Korean J. Opt. and Photon. 22, $72-76$ (2011).

12. U.-S. Jung, N.-H. Cho, S.-H. Kim, H.-S. Jeong, J.-H. Kim, and Y.-C. Ahn, "Simple spectral calibration method and its application using an index array for swept source optical coherence tomography," J. Opt. Soc. Korea 15, 386-393 (2011).

13. A. Bilenca, S. H. Yun, G. J. Tearney, and B. E. Bouma, "Numerical study of wavelength-swept semiconductor ring lasers: the role of refractive-index nonlinearities in semiconductor optical amplifiers and implications for biomedical imaging applications," Opt. Lett. 31, 760-762 (2006). 